Brazilian Journal of Political Economy, vol. 40, $n^{\circ}$ 4, pp. 712-727, October-December/2020

\title{
The role of credit in regional divergence: Spanish regions and Eurozone countries
}

\author{
O papel do crédito na divergência regional: \\ regiões espanholas e países da Zona do Euro
}

\author{
SHEILA C. DOW * \\ CARLOS J. RODRÍGUEZ-FUENTES *
}

\begin{abstract}
RESUMO: Este artigo fornece uma explicação teórica do papel das diferenças regionais nos padrões cíclicos de disponibilidade de crédito para padrões de convergência ou divergência regional. Embora as teorias dominantes impliquem equalização dos fluxos regionais de capital ou menor disponibilidade de crédito para regiões periféricas devido a imperfeições do mercado, a teoria pós-keynesiana de preferência pela liquidez e estrutura financeira implica o espaço para uma maior volatilidade de crédito para regiões periféricas, especialmente em períodos de crise, contribuindo para divergência econômica real. Esta última conta é avaliada por meio de uma análise empírica dos padrões de crédito bancário durante o ciclo de negócios entre as regiões espanholas e os países da zona do euro.

PALAVRAS-CHAVE: Prociclicidade de crédito; preferência pela liquidez; teoria de crédito regional pós-keynesiana; Human P. Minsky.
\end{abstract}

ABSTRACT: This paper provides a theoretical account of the role of regional differences in cyclical patterns of credit availability for patterns of regional convergence or divergence. While mainstream theories imply either equalising regional capital flows, or else lower credit availability for peripheral regions due to market imperfections, Post-Keynesian theory of liquidity preference and financial structure imply the scope for greater credit volatility for peripheral regions, especially in downturns, contributing to real economic divergence. This latter account is assessed by means of an empirical analysis of patterns in bank credit over the business cycle among the Spanish regions and Eurozone countries.

KEYWORDS: Credit procyclicality; liquidity preference; Post-Keynesian regional credit theory; Human P. Minsky.

JEL Classification: B5; E5; R11.

\footnotetext{
* Department of Economics, University of Stirling, Stirling, Scotland. E-mail: s.c.dow@stir.ac.uk. Orcid: http://orcid.org/0000-0001-9969-197X

* Departamento de Economía Aplicada y Métodos Cuantitativos, Universidad de La Laguna, La Laguna, Spain. E-mail: cjrodrig@ull.edu.es. Orcid: http://orcid.org/0000-0002-6831-0588. Submitted: 22/April/2019; Approved: 9/October/2019.
} 


\section{INTRODUCTION}

There is growing empirical evidence that the establishment of EMU has not led to greater economic convergence within the euro area (Martin, 2001; Fingleton, Garretsen and Martin, 2015, and Cuadrado-Roura, Martin and Rodriguez-Pose, 2016). In particular there is growing concern over the central role that monetary integration has played in promoting greater financialisation within the Eurozone (Rossi, 2013, and Arestis, Fontana and Phelps, 2017) and greater disparities in financial instability (Martin, 2011). The financial crisis has made the scope for divergence in real economic conditions and credit availability increasingly evident (Martin, 2011, and Dijkstra, Garcilazo and McCann, 2015).

From a mainstream perspective, O'Brien's "end of geography" claim for finance implies that, since credit instability was so widespread during the crisis, it is of little spatial consequence (Martin, 2011: 590). The purpose of this paper is to challenge such an argument. If divergence in both financial and real economic conditions is interrelated, then credit instability has a spatial dimension which should be explored. We provide a theoretical framework which explains forces for regional divergence in terms of the interrelationship between financial and real conditions. We then consider how far this argument is borne out by the evidence. Specifically, we explore empirical evidence on credit availability, differentiating between low and high income economies in Spain and in the Eurozone and among different phases of the business cycle.

In terms of mainstream monetary theory, differences in regional credit availability are market-efficient since they are, not only the outcome of a profit-maximising process, but also temporary: they will disappear in the long term as a result of the catch-up process and a higher degree of business cycle synchronisation. But, as Turner (2012) points out, this theory paid scant attention to banks as the creators of credit. He challenges the assumption that increased financial market efficiency is socially optimal, particularly with respect to credit instability. Here we take a regional perspective, considering the scope for poorer economies/regions to exhibit a more unstable pattern in credit availability, and arguing that this cannot be explained solely by relatively poor economic performance. Indeed, this performance may be reinforced by credit instability, promoting divergence rather than convergence. Rather, higher credit instability, and its within-cycle character, may be explained also by particular patterns of financial behaviour and financial structure, specifically the procyclical changes in the liquidity preference of economic agents and by spatially-differing banking strategies.

This argument is developed in the second section, where we consider these two key elements of the Post-Keynesian theory of regional credit (Chick and Dow, 1988, and Dow, 1990), namely liquidity preference and stages of banking development (Chick, 1986 and 1988), together with Minsky's theory of financial instability (Minsky, 1982). On this basis we aim to explain the strong procyclicality that bank credit has exhibited in the poorer Spanish regions, which is illustrated in the third section, and some European countries, as shown in the fourth section. Our results, 
which are summarised and discussed in the fifth section, suggest that poorer regions (in Spain) and countries (in the Eurozone) show, not only stronger fluctuations in credit growth over the business cycle, but also particularly stronger contractions in recessions. Whereas the evidence found in this paper for the Spanish regions extends the scope of previous contributions (see Rodriguez-Fuentes, 1998, and RodriguezFuentes and Dow, 2003), the results for the Eurozone broaden the scope of previous work in the field (such as Mackay and Molyneux, 1996, and Martin, 2001).

\section{INTERPRETING MONETARY THEORY FROM A SPATIAL PERSPECTIVE: THE POST-KEYNESIAN THEORY OF REGIONAL FINANCE}

The way in which financial relations operate, and interact with the real sector, is central to business cycle theory, and provides the basis for considering the role of finance in regional economic development. But there are marked differences among different approaches to macroeconomic theory as regards the business cycle, which carry over into the regional context. In this section we explore Post-Keynesian macroeconomic theory in comparison with the traditional, and more recentlydeveloped, mainstream alternatives, in order to set out a regional macroeconomic theory. This will provide the framework within which we will consider the evidence for the Spanish regions and for member states within the Eurozone.

Traditionally, the general equilibrium framework of mainstream macroeconomic theory has emphasised the capacity of competitive markets to restore themselves to equilibrium, with equalised returns, whenever that equilibrium is disturbed. ${ }^{1}$ Financial markets play a key role in this process, ensuring that finance flows to the highest returns, thus reducing returns at the margin (assuming downward-sloping marginal productivity) until they are equalised. Business cycles are understood to be the result of an exogenous disturbance which is amplified until expectations adjust and then settles down again to equilibrium. Different theories have analysed the disturbance variously as arising from monetary shocks and real shocks. In one version of the analysis of a monetary shock, a surprise loosening of monetary policy encourages banks to create more credit, financing more investment. When the resulting inflation (given the assumption of full employment) erodes expected real returns, the process goes into reverse.

While this analysis has traditionally been applied to time, its regional variant has been applied also to space (see e.g. Beare, 1976, Mathur and Stein, 1980, and

\footnotetext{
${ }^{1}$ The mainstream argument for the neutral role for money in a regional setting is, to some extent, a combination of the conventional monetarist money-neutrality argument (Friedman and Meiselman, 1963 ) and the assumption of perfect interregional capital mobility, inspired by the analysis put forward by Ohlin (1933) about interregional and international free trade. For further details on the neutral role for money in a regional setting, see Dow (1990: chapter 2, page 10), Holland (1976: chapter 2) and Dow and Rodriguez-Fuentes (1997: 905-913).
} 
Miller, 1980). ${ }^{2}$ Ceteris paribus, competitive national financial markets are assumed to equalise returns across regions. Where a shock is region-specific (normally a real shock, such as a new natural resource discovery in one region), the flow of finance into that region would occur until returns are equalised within a new configuration of real activity. The persistence of real regional differences can then only be explained in such a framework by some factor counteracting the operation of competitive market forces, such as fiscal redistribution. To the extent that peripheral regions benefit from increased redistribution in economic downturns, returns on capital will be kept artificially high and the capital outflows required to restore returns to the national norm will be impeded. The implication is higher net capital inflows (including higher credit creation) to peripheral regions than implied by real economic conditions, especially in economic downturns (Courchene, 1981).

More recent developments in mainstream theory have focused much more on impediments to market forces, particularly in the case of New Keynesian theory, whose focus on credit is particularly apposite for our analysis (Dixon, 2008). New Keynesian theory emphasises the importance of information asymmetry in understanding credit availability. Concealed information about risk encourages banks to ration credit when monetary policy is tightened. Among banks located in the financial centre, information is in general poorer on borrowers in peripheral regions and their projects. Credit availability for peripheral regions will accordingly tend to be more constrained than for other regions as the business cycle approaches its peak. ${ }^{3}$ Further, arguably, since poorer information on peripheral borrowers is a general phenomenon, New Keynesian analysis could be extended over the cycle, predicting perpetually-reduced levels of credit throughout the business cycle compared to what real conditions would appear to warrant, impeding equilibrating forces and allowing real regional differences to persist.

Post-Keynesian macroeconomic theory provides a very different account of the business cycle and its regional composition. Rather than regarding the cycle as an aberration, Post-Keynesian theory regards real and financial instability as the norm. Real instability follows from the amplification through the supermultiplier of fluctuating investment. These fluctuations in turn follow from investment being based on expectations which, particularly for the long time-frame of capital investment, are fundamentally uncertain. While conventional judgement and well-functioning institutions (such as central banks devoted to promoting financial and monetary stability) lend stability to the process, the potential is always there for uncertainty

\footnotetext{
2 The pioneering works by Beare (1976), Mathur and Stein (1980) and Miller (1980) represent good examples of regional applications of the monetarist view regarding the neutral effect of money on regional growth in the long run.

${ }^{3}$ It is implicit in this framework that there is no particular benefit for peripheral regions when monetary policy is loosened from equilibrium. Since tightening monetary policy creates unsatisfied demand, loosening it again to the original state does reverse this credit rationing (returning the market to the demand curve). But banks respond to any loosening from an equilibrium state by reducing loan rates for all, simply moving the market down the demand curve.
} 
to increase, causing investment to falter, which in a systemic way can create a cyclical downturn. The reversal of this downturn can lack force unless, according to Keynesian policy prescriptions, government intervenes to boost effective demand. While the New Keynesian approach refers to risk assessment as an objective process, where in principle full information would allow the generation of a risk measure, the Post-Keynesian approach rather sees all credit-risk assessment as being subject to uncertainty of varying degrees (Dow, 1995, 1998 and 2004). That uncertainty is perceived to be greater the more remote the borrower from the lender, where remoteness may be spatial, cultural, etc. (see Porteous, 1995).

Second, in contrast to the equilibrating role of finance in mainstream theory, the financial sector in Post-Keynesian theory can be expected to exacerbate real instability. Minsky's (1982, chapter 5) financial instability hypothesis analyses the increasing financial fragility which accompanies an economic upturn, as over-confidence (among lenders and borrowers alike) in increasing returns on real as well as financial assets encourages ever-greater financial leverage, evidenced by increasing levels of debt. While a real cyclical upturn may peak as the increase in expected returns slows down, credit can continue to increase to finance investment instead in speculative assets. But when expectations of increases in financial returns are punctured by some event (e.g., the realisation of the extent of risk in the US subprime mortgage market), the process goes into reverse. Credit supply falls as perceived risk rises, exacerbating cash-flow constraints just as liquidity preference rises. The resulting sell-off of assets reduces the value of collateral further increasing credit risk. The pro-cyclical credit cycle is driven by expectations, and the degree of confidence in expectations under uncertainty, as they affect both lenders and borrowers. Crucially, while New Keynesian theory focuses on credit supply when monetary conditions tighten, Post-Keynesian credit theory focuses equally on credit supply and demand, throughout the cycle. Further, while New Keynesian theory allows only for credit below 'equilibrium' levels (rationing), Post-Keynesian theory allows for the possibility of credit supply both in excess of, as well as below, what is reasonable. ${ }^{4}$

The experience during the cycle will vary across regions, depending on regional differences in expectations and in banking structure, affecting both demand for and supply of credit. Central regions tend to host the head offices of large companies, the head offices of national banks, the highest property values, the locus of securities markets and the greatest concentration of wealth held in those assets. Even under uncertainty, the most reliable knowledge of the value of these assets resides in the centre, encouraging a stable supply of credit (see e.g. Chick and Dow, 1988, and Porteous, 1995). By contrast, knowledge of the value of assets in peripheral regions will be less reliable. This in itself can cause grater instability of credit supply. When there is a natural resource discovery, for example, in a peripheral

\footnotetext{
${ }^{4}$ For further details on the crucial differences between the New Keynesian and Post-Keynesian view on the underlying factors determining both regional credit availability and its variations alongside business cycles, see Dow and Rodríguez-Fuentes (1997: 912-916).
} 
region, the more unreliable basis for expectations of their value can lead to overconfidence and an unduly enthusiastic supply of credit. But when that confidence is punctured by events, the over-supply of credit can go rapidly into reverse. We saw this pattern in the 1990s with the build-up to the south-east Asia crisis and its aftermath.

Long experience of this kind of volatility in credit availability in peripheral economies, together with a lower asset base to act as a cushion, encourages a higher secular level of liquidity preference (on which cyclical variations are overlaid). Dow (1992) has labelled this 'defensive financial behaviour'. Since assets in central regions are more liquid than those in peripheral regions, one consequence of higher liquidity preference in peripheral economies is capital outflows. But further consequences which hold down development prospects in peripheral economies are a greater unwillingness among firms to take on debt, with fixed servicing, to finance real investment, and among households to take on debt to finance consumption which would have bolstered the profit potential of local firms.

It is important also to consider the financial structure within which this regionally-differentiated behaviour plays out. This was central to the financial instability hypothesis developed by Hyman P. Minsky (1982) to capture the potentially destabilising interplay between finance and real activity over the cycle. Back in 1965 , when studying the contribution of the banking system to the rapid growth experienced by California, Minsky had distinguished the three following categories with regard to the contribution of banking to regional growth: absorbing, amplifying or neutral (Minsky, 1965: 125). Minsky considered that "for shocks at all severe, a financial system, to act as an absorber, requires 'central bank' support" (Minsky, 1965: 126). Though Minsky died well before the 2007 Great Financial Crisis, he would not have been surprised at all by its eruption. But he would also probably have welcomed the central banks" "unconventional" policies, such as quantitative easing (which was often questioned by mainstream economists concerned about inflationary consequences (see e.g. Thornton, 2010). The 2007 Crisis was a "severe" shock whose adverse effects could only be absorbed with central bank support, where by "central bank" he understood, not only the monetary authority, but also other governmental or quasigovernmental institutions.

A financial system acts as an amplifier of depressing shocks when three consequences occur: (1) when losses of the financial system are passed on as widespread losses to the holders of financial system liabilities; (2) when the way in which financial organizations attempt to protect themselves against losses generates greater losses and defaults than would otherwise occur; and (3) when financing conditions tighten whenever income has fallen. A financial system is neutral when it neither absorbs nor amplifies shocks (Minsky, 1965: 126).

Focusing on bank structure in relation to real and financial behaviour, Chick's (1986 and 1988-1993) stages of banking development framework tracks how bank- 
ing systems evolve in such a way as to meet the needs of borrowers in an ever-more efficient way. Yet in recent decades, deregulation has allowed banks to focus attention more on maintaining their own liquidity and profitability, at the expense of the real sector. Banks in peripheral economies have tended to be further behind those in the centre in terms of banking development. One implication has been that their capacity to create credit has been more limited than centre banks at a later stage of development. ${ }^{5}$ The other is that they find it hard to compete in a national banking market. Thus deregulation has squeezed out the local banks which had been operating on more traditional lines, better serving their local economies. This has been the case for Spain (Chick, Dow and Rodriguez-Fuentes, 2013). In the Eurozone, the aim has always been to create a single banking market, assuming that competition on a level regulatory playing field would promote welfare-enhancing equilibrium (European Commission, 1990). However, although credit growth was strong during the last expansionary boom in remoter euro countries, those countries also experienced a clear drop in credit growth not only after the irruption of the crisis, but also during the recovery from 2013 onwards. The effect we would expect is that, far from enhancing integration of peripheral regions into the national financial sector and thus enhanced access to credit, the process of centralisation has exacerbated the problems of less reliable information on peripheral borrowers and the value of peripheral assets.

In the case both of the Spanish regions and the members of the Eurozone, then, Post-Keynesian theory would suggest a greater pro-cyclical volatility of credit levels in peripheral economies over the business cycle, compared to steady growth in the centre, and a secular tendency for lower credit growth. This contrasts with the prediction of traditional mainstream theory, that regional credit supply would be counter-cyclical, following heightened marginal returns and encouraged by regional policy. It also contrasts with New Keynesian theory of credit supply, which implies stronger credit rationing in peripheral economics as monetary conditions tighten, i.e., reduced credit volatility, and possibly also a secular trend towards lower credit availability over the cycle.

Post-Keynesian theory posits a set of causal mechanisms whereby credit levels are expected to be more volatile in peripheral economies than in centre economies over the cycle, as an integral part of a process which allows economic divergence to persist. Indeed, the less segmentation in the financial market (among regions, or nations in a currency area), the greater the possibility for forces for divergence (while mainstream theory would suggest the opposite). Identifying separate causal mechanisms empirically is very challenging, given the posited interdependence between credit supply and demand, real expenditure plans, as well as the dependence of money on credit creation. The question then is not whether banks lend more

\footnotetext{
${ }^{5}$ The basis for this argument is both the earlier stage of banking development (see Chick, 1986, and Chick and Dow, 1988) and the higher fluctuations in liquidity preference over business cycles in peripheral regions (for further details, see Dow and Rodríguez-Fuentes, 1997: 914-916).
} 
than they borrow regionally, as is often suggested, or how a fixed amount of credit is divided up among regions, but how credit is created (or not) regionally. Here we limit the empirical enquiry to a comparison between the patterns of credit in peripheral economies and centre economies over the business cycle.

\section{REGIONAL CREDIT PROCYCLABILITY IN SPAIN, 1988-2016}

This section aims at characterising, empirically, the cyclical pattern of regional bank credit in Spain. The data set employed, which ranges from year 1988 to 2016, consists of the annual rates of growth of bank credit and GDP for the 17 NUTS-1 Spanish regions. The bank credit variable, which represents the total outstanding amount of loans provided by the banking system to both private and public sector in Spanish regions, was extracted from chapter 4 of the Bank of Spain Statistical Bulletin. Since the original data were available on a quarterly base, the yearly observation was calculated as the corresponding average value from quarterly observations. The GDP variable, which corresponds to Gross Domestic Product at market prices in constant terms, was extracted from the "Instituto Nacional de Estadística" (INE - Contabilidad Regional de España), for the period 1987-2014. The data for years 2015 and 2016 were completed with the data set provided by De la Fuente (2019).

The empirical test conducted in this section consists in the estimation of the following panel regression (with fixed effects) specification:

$$
\text { Credit }_{i, t}=\alpha_{0}+\alpha_{1} \text { Cycle }_{t}+\beta_{0} G D P_{i, t}+\beta_{1} G D P_{i, t} \text { Cycle }_{t}+\mu_{t}
$$

where Credit and GDP are the annual rates of growth of bank credit and Gross Domestic Product for every region, respectively, and Cycle is a dummy variable that takes value 1 for the sample observations corresponding with recessionary periods, and 0 otherwise. Subscripts $\mathrm{i}$ and $\mathrm{t}$ stand for every region and year considered in our panel. The econometric estimation of equation 1 was performed with gretl 2017c free software (GNU Regression, Econometric and Times-series Library), and the results are shown in Table 1.

We are interested not only in quantifying the differences in the response of bank credit to GDP cycles among the different groups (wealthier and poorer ones) of regions in Spain ( $\beta_{0}$ in equation 1 ) but also to different phases (expansions and recessions) of the national business cycle ( $\beta_{1}$ in equation 1 ). Consequently, in order to account for the differences in the cyclical response of credit between the wealthier and poorer regions, the 17 Spanish regions were pooled into different groups according to their relative GDP per capita so we can compare the estimated value for $\beta_{0}$ among the different groups. We have considered the following four groups: Ultra Core (UC), Ultra Periphery (UP), Core (C) and Periphery (P). The wealthier group is Ultra Core (UC), which contains four regions with a GDP per capita (at least) 1.2 times the Spanish average. The Ultra Peripheral group contains six regions 
Table 1: Panel data estimates (fixed effects) for Spanish regions, 1988-2016

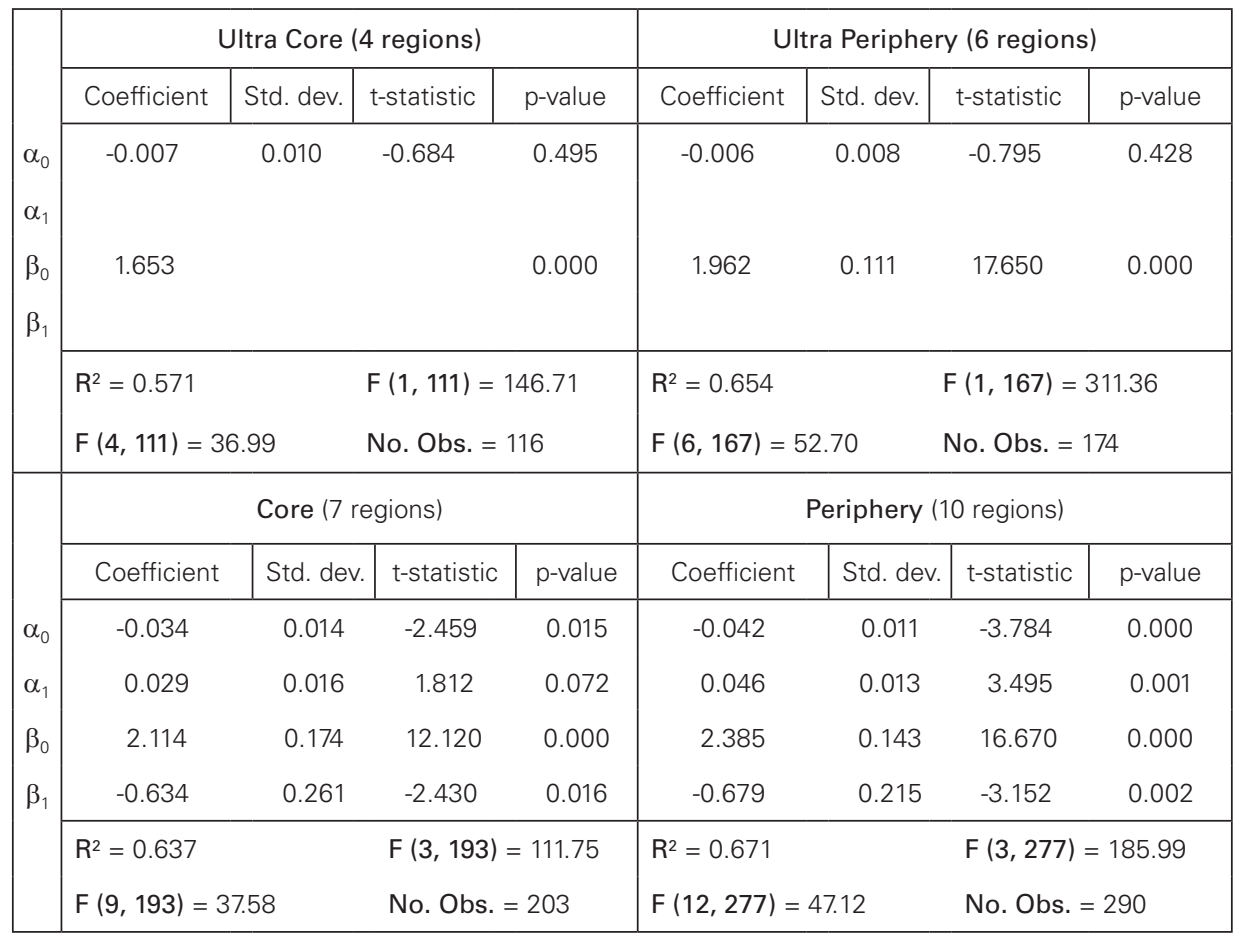

Note: Estimates using "gretl 2017c" free software.

with a GDP per capita below $80 \%$ of Spanish average. The Core group results from adding three regions (with a GDP per capita ranging from 1.1 to 1.2 times the Spanish average) to the Ultra Core group. Finally, the Periphery group results from adding four regions (with a GDP per capita between $80 \%-90 \%$ of Spanish average) to the Ultra Periphery group.

Additionally, in order to take into account the differences between the expansionary and recessionary phases of the Spanish business cycle $\left(\beta_{1}\right.$ in equation 1$)$, we have included a qualitative variables (Cycle) to account for the recessionary periods, which we identified by using the Hodrick-Prescott filter. Explicitly we considered two alternative dummies with very slight differences. Whereas both dummies refer to the years 2009-2013 as a recessionary period, they differ in that one considers the three years 1992-1994 as a recession, whereas the other considers only year 1993 as such. The sample contains a long period (13 years corresponding to 1995-2007) of sustained economic growth (during which nominal GDP grew by around $7.5 \%$ per annum) and 5 observations (corresponding to 2008-2013) of strong recession, during which nominal GDP experienced a negative annual growth rate of $1.6 \%$. It is worth noting that lower income regions (Ultra Periphery) exhibited a stronger contraction during this period, since their negative growth went down to $2.0 \%$, whereas the wealthier regions (Ultra Core) experienced a negative growth of $1.2 \%$.

The results of our estimates show a higher business cycle sensitivity of credit 
growth among the poorer regions. According to our estimates, the response of the rate of growth of credit in the Ultra Periphery group is 1.2 times the response in the Ultra Core (1.96 vs 1.65), both during upturns and downturns. This is also true for the Periphery and Core groups, since the cyclical response of credit in the Periphery is 1.1 (2.39 vs 2.11 ) and 1.2 (1.71 vs 1.48$)$ times the value for the Core during the expansionary and recessionary periods, respectively.

Finally, by combining the calculated average GDP growth in our data $\operatorname{set}^{6}$ and the numerical estimates shown in Table 1, we arrive at the growth rates for credit in the four groups considered (as shown in Figure 1).

Figure 1: Calculated credit rates of growth (\%) in expansion and recession

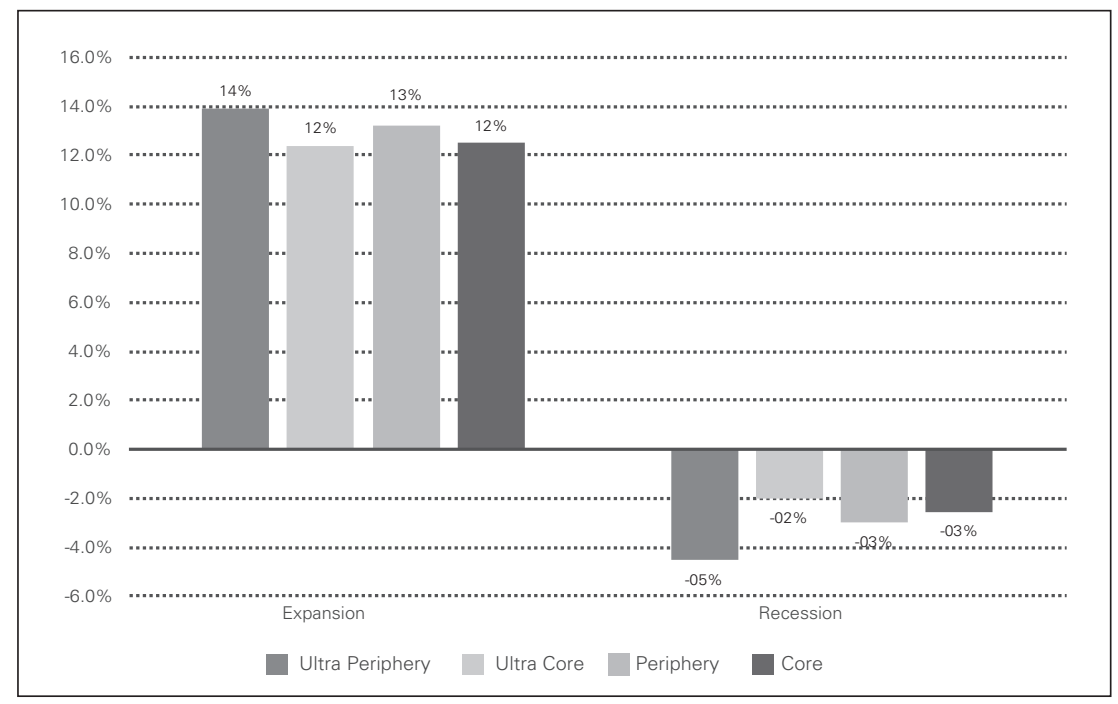

Source: Own calculations.

Figure 1 shows not only higher values for credit growth among poorer regions in Spain during upturns, but also greater contractions in credit (lower rates of growth) during recessionary periods. Whereas the Ultra Periphery group exhibits a reduction of about 18.4 percentage points (pp) in the credit growth rate within business cycles (from a positive rate of 13.9 to a negative value of 4.5), the Ultra Core regions show a lower contraction $(14.4 \mathrm{pp})$. A similar result arises from the comparison between Periphery and Core, although in this case the difference between the groups is smaller ( $16.2 \mathrm{pp}$ vs $15.0 \mathrm{pp})$. These results confirm previous results on the more unstable (or procyclical) pattern for credit availability in low income regions in Spain, especially in downturns (see Rodriguez-Fuentes, 1998, and Rodriguez-Fuentes and Dow, 2003).

\footnotetext{
${ }^{6}$ The calculated GDP growth of rate are as follows. For the expansion, $7.4 \%$ for UP, $7.5 \%$ for UC, $7.3 \%$ for P and $7.5 \%$ for C. For the recession, $-2.0 \%$ for UP, $-1.2 \%$ for UC, $-2.0 \%$ for P and $-1.4 \%$ for C.
} 
This section studies the cyclical pattern of bank credit in 12 Eurozone economies, the 11 countries that started in 1999 and Greece, which joined the Eurozone two years later. These 12 economies have been pooled intro four groups. Two of these groups correspond to the so-called core economies, whereas the others include some of the Eurozone economies most affected by the 2008 recession: Portugal, Ireland, Greece and Spain. The sample, which contains the quarterly rates of growth of bank credit and GDP for these four, extends from 1999 to 2017. The data for banking credit, which corresponds to the total outstanding amounts of loans provided by the Monetary and Financial Institutions (MFI) to private sector, was extracted from the Statistical Data Warehouse of the European Central Bank. The GDP variable corresponds to the Gross Domestic Product at market prices (chained linked volumes), from ESA95 account, and was extracted from Eurostat.

The empirical analysis reported in this section, which aims at quantifying the response (sensitivity or elasticity) of bank credit to GDP business cycles in each of the aforementioned country groups, consists in the estimation of the following panel regression specification:

$$
\text { Credit }_{i, t}=\alpha_{0}+\alpha_{1} \text { Cycle }_{t}+\beta_{0} G D P_{i, t}+\beta_{1} G D P_{i, t} \text { Cycle }_{t}+\mu_{t}
$$

where Credit and GDP are the annual rates of growth of bank credit and Gross Domestic Product for the Eurozone economies considered, respectively, and Cycle is a dummy variable that takes value 1 for the sample observations corresponding with recessionary periods, and 0 otherwise. As in the third section, the qualitative variable Cycle was identified by using the Hodrick-Prescott filter. Subscripts i and $\mathrm{t}$ stand for every national economy and year considered in our panel.

The results of the econometric estimation of equation 2, which are shown in Table 2, show that group made up of Portugal, Greece and Spain (PGS) exhibits the highest value (1.58) for the estimated response in the rate of growth of credit to GDP both during upturns and downturns. This value almost triples the corresponding value for the Core 6 during the expansionary periods $(0,55)$ and (more than) doubles the one for the Core 8 (0.72). During recessionary periods, this pattern is even stronger since the response of credit to GDP in the PGS groups triples the corresponding value for the Core groups $(0.55$ for Core 6 and 0.50 for Core 8 ). Although the inclusion of Ireland (PIGS) leads to a much lower estimated value for the response of credit to GDP growth (from 1.58 to 0.46 ), this is only true for the expansions, since the group PIGS exhibits a parameter close to PGS for the recessionary periods (1.54 vs 1.58$)$. 
Table 2: Panel data estimates (fixed effects)

for Eurozone economies, 1999:Q1-2017:01

\begin{tabular}{|c|c|c|c|c|c|c|c|c|}
\hline \multirow[b]{3}{*}{$\alpha_{0}$} & \multicolumn{4}{|c|}{ Core (8 countries) } & \multicolumn{4}{|c|}{ Ultra Core (6 countries) } \\
\hline & Coefficient & Std. dev. & t-statistic & p-value & Coefficient & Std. dev. & t-statistic & p-value \\
\hline & 0.028 & 0.004 & 7.696 & 0.000 & 0.031 & 0.005 & 6.627 & 0.000 \\
\hline$\beta_{0}$ & 0.721 & 0.089 & 8.102 & 0.000 & 0.551 & 0.097 & 5.679 & 0.000 \\
\hline$\beta$ & -0.225 & 0.126 & -1.784 & 0.075 & & & & \\
\hline & $R^{2}=0.268$ & & \multicolumn{2}{|c|}{$F(2,574)=33.687$} & \multicolumn{2}{|l|}{$R^{2}=0.263$} & \multicolumn{2}{|c|}{$F(1,431)=32.248$} \\
\hline & $F(9,574)=$ & 23.349 & \multicolumn{2}{|c|}{ No. Obs. $=584$} & \multicolumn{2}{|c|}{$F(6,431)=25.623$} & No. Obs. $=$ & \\
\hline & \multicolumn{4}{|c|}{ PGS ( 3 countries) } & \multicolumn{4}{|c|}{ PIGS (4 countries) } \\
\hline \multirow{7}{*}{$\begin{array}{l}\alpha_{0} \\
\alpha_{1} \\
\beta_{0} \\
\beta_{1}\end{array}$} & Coefficient & Std. dev. & t-statistic & $\mathrm{p}$-value & Coefficient & Std. dev. & t-statistic & p-value \\
\hline & 0.032 & 0.008 & 4.125 & 0.000 & 0.061 & 0.011 & 5.644 & 0.000 \\
\hline & & & & & -0.038 & 0.017 & -2.228 & 0.027 \\
\hline & 1.584 & 0.140 & 11.330 & 0.000 & 0.460 & 0.137 & 3.354 & 0.001 \\
\hline & & & & & 1.081 & 0.241 & 4.478 & 0.000 \\
\hline & \multicolumn{2}{|l|}{$R^{2}=0.389$} & \multicolumn{2}{|c|}{$F(1,215)=128.431$} & \multicolumn{2}{|l|}{$R^{2}=0.212$} & \multicolumn{2}{|c|}{$F(3,285)=23.723$} \\
\hline & \multicolumn{2}{|c|}{$F(3,215)=45.546$} & \multicolumn{2}{|c|}{ No. Obs. $=219$} & \multicolumn{2}{|c|}{$F(6,285)=12.816$} & \multicolumn{2}{|c|}{ No. Obs. $=292$} \\
\hline
\end{tabular}

Note: Estimates using "gretl 2017c" free software.

Finally, combining the calculated average GDP growth in our data $\operatorname{set}^{7}$ and the numerical estimates shown in Table 2, yields the growth rates for credit in the four groups considered (Figure 2).

Again, as shown in the third section for the lower-income regions in Spain, Figure 2 shows not only higher values for credit growth in the PGS and PIGS groups during upturns, but also higher contractions (and even negatives rates of growth) during recessionary periods, whereas both Core 6 and Core 8 exhibit positive growth during the recession.

\footnotetext{
${ }^{7}$ For the expansion we have considered the average GDP rate of growth during 1991:Q1-2007:Q4, resulting as follows: $3.6 \%$ and $3.5 \%$ for Core 6 and Core 8 , respectively, and $6.3 \%$ and $7.3 \%$ for PGS and PIGS, respectively. For the recession (we have considered 2008:Q3-2009:Q4) we have considered the following: $-0.5 \%$ and $-0.7 \%$ for Core 6 and Core 8 , respectively, and $-2.6 \%$ and $-3.4 \%$ for PGS and PIGS, respectively.
} 
Figure 2: Calculated credit rates of growth (\%) in expansion and recession

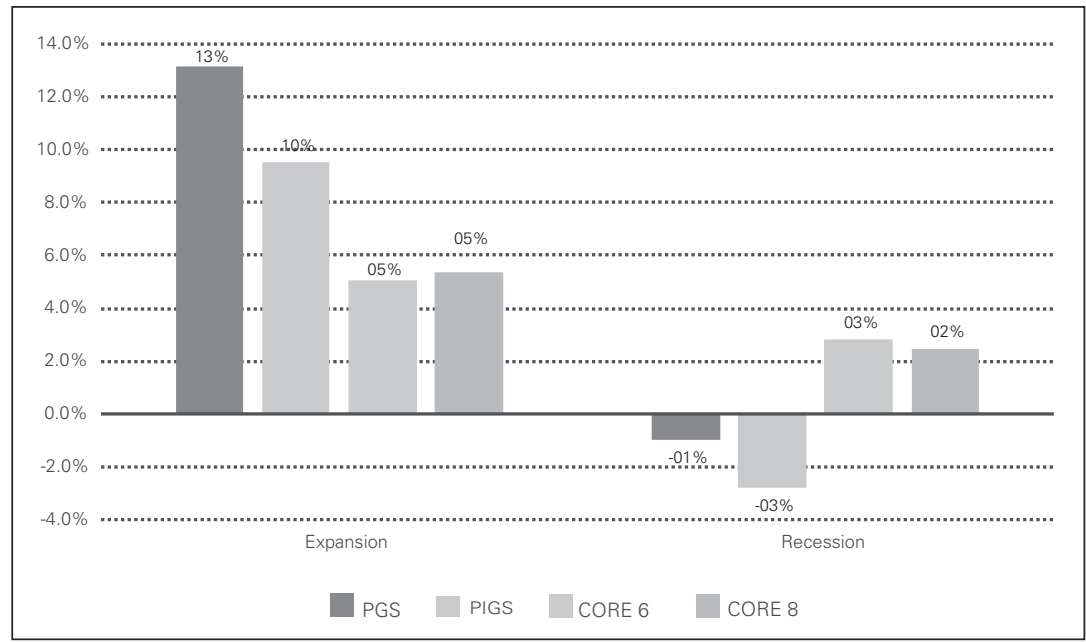

Source: Own calculations.

\section{CONCLUSIONS}

One of the ruling principles of mainstream theory is that banks, as financial intermediaries, play a neutral role in regional economic growth since they simply facilitate the optimal spatial allocation of savings into investment across regions within a national economy.

Although this conventional perspective has been dominant within the literature on regional finance, other alternative contributions have questioned its relevance. Mainstream macroeconomic theory excludes any consideration of the historical and institutional particularities that would lead to a better understanding of the many (and evolving) ways through which money, monetary policy and the banking system can influence economic development (Chick and Dow, 1988). But also this approach overlooks the fact that the supply of credit "never occurs in isolation", so its effects would always depend on "how people behave, who issues the money and in exchange for what" (Chick, 1978: 55-58).

The analysis conducted in this paper aims at contributing to this second strand of literature, a literature that was briefly summarised in the second section, and argues that the banking system may influence the regional growth process by producing a more unstable and pro-cyclical patter in the availability of credit in peripheral economies. We have approached this issue empirically by studying differences in the response of bank credit to GDP cycles among the different groups considered (wealthier and poorer economies, in Spain and the Eurozone) during business cycles. The numerical results shown in our work refer only to correlation; like any correlations, they are indicative rather than conclusive about causal mechanisms. However, we have set out a theoretical framework which generates several 
"tentative conclusions" and shown that these are compatible with the empirical results. The analysis goes further by putting forward some explanations about the potential non-neutral consequences that banking may have for divergent regional growth patterns.

Our empirical approach addresses the methodological issues raised by Chick (1978), and our results support the amplifying character of the banking system which Minsky (1965) had identified, since the strong fluctuations observed in credit availability in the recessionary periods seem to affect poorer economies more strongly. The results reported in our paper show that poorer regions (in Spain) and countries (in the Eurozone) show stronger fluctuations in credit growth over the business cycle, with particularly stronger contractions in recessions. In particular, for the Spanish regions our results show, not only higher values for credit growth among poorer regions in Spain during upturns, but also higher contractions in credit during recessionary periods: whereas the poorest-regions group exhibits a range of about 18.4 percentage points $(\mathrm{pp})$ in the credit growth rate over business cycles (from a positive rate of 13.9 to a negative value of 4.5), the wealthiest group shows a smaller range (14.4 pp). Our results for the different Eurozone group pf countries lead us to the same conclusion: the lower-income groups exhibit higher values for credit growth during upturns, but also higher contractions (and even negatives rates of growth) during recessionary periods, whereas the wealthier groups register positive growth even during the during the recession phase.

These results are consistent with the Post-Keynesian theory of regional finance set out in the second section, but not with either traditional mainstream theory or New Keynesian theory. In turn they help us to understand the absence of the real economic convergence (and indeed forces for convergence) among regions which mainstream theory would lead us to expect.

\section{REFERENCES}

Alessandrini, P., Presbitero, A. F. and Zazzaro, A. (2009) "Global banking and local markets: a national perspective”, Cambridge Journal of Regions, Economy and Society, 2: 173-192.

Arestis, P. and S. Dow (eds) (1992) On Money, Method and Keynes: Selected Essays by Victoria Chick. London: Macmillan/St Martin's Press.

Arestis, P., Fontana, G. and Phelps, P. (2017) "Regional financialisation and financial systems convergence: evidence from Italy", Environment and Planning A, 49(1): 141-167.

Beare, J. B. (1976) “A monetarist model of regional business cycles”, Journal of Regional Science, 16(1): 57-63.

Chick, V. (1978) "Unresolved questions in monetary theory: a critical review", De Economist, 126(1): 36-60 [reprinted in P. Arestis and S. Dow (eds) (1992), 143-166].

Chick, V. (1986) "The evolution of the banking system and the theory of saving, investment and interest", Economies et Sociétés 20, Monnaie et Production, 3: 111-126.

Chick, V. (1988) "The evolution of the banking system and the theory of monetary policy", Paper presented at the Symposium on Monetary Theory and Monetary Policy: New Tracks for the 1990s, the Free University of Berlin, Berlin, 31 August - 2 September [reprinted in S.F. Frowen (ed.) (1993) Monetary Theory and Monetary Policy: New Tracks for the 1990s. London: Macmillan, 79-92]. 
Chick, V. and S. Dow (1988) "A Post-Keynesian perspective on the relation between banking and regional development", Thames Papers in Political Economy, Spring: 1-22 [reprinted in P. Arestis (ed.) (1988) Post Keynesian Monetary Economics: New Approaches to Financial Modelling. Cheltenham: Edward Elgar, 219-250].

Chick, V., S.C. Dow and C.J. Rodriguez-Fuentes (2013) “Good banks and bad banks, centralised banks and local banks and economic growth", Ekonomiaz, 84(3): 110-127.

Courchene, T.J. (1981) “A market perspective on regional disparities”, Canadian Public Policy, 7(4): 506-518.

Cuadrado-Roura, J. R., Martin, R. and Rodríguez-Pose, A. (2016) "The economic crisis in Europe: urban and regional consequences", Cambridge Journal of Regions, Economy and Society, 9: 3-11.

De la Fuente, A. (2017), "Series largas de algunos agregados económicos y demográficos regionales”. Madrid: FEDEA.

Dijkstra, L., Garcilazo, E. and McCann, P. (2015) "The effects of the global financial crisis on European regions and cities", Journal of Economic Geography, 15: 935-949.

Dixon, H.D. (2008) "New Keynesian macroeconomics", in S.N. Durlauf and L.E. Blume (eds) The New Palgrave Dictionary of Economics, Second Edition. London: Palgrave Macmillan.

Dow, S C and Rodriguez-Fuentes, C J (1997) "Regional Finance: A Survey”, Regional Studies, 31(9): 903-20.

Dow, S.C. (1990) Financial Markets and Regional Economic Development: The Canadian Experience, Aldershot: Avebury.

Dow, S.C. (1992) "The regional financial sector: a Scottish case study", Regional Studies, 26(7): 619631.

Dow, S.C. (1995) “Uncertainty about uncertainty”, in S.C. Dow and J. Hillard (eds) Keynes, Knowledge and Uncertainty. Aldershot: Edward Elgar, 112-127.

Dow, S.C. (1998) "Knowledge, information and credit creation", in R.J. Rotheim (ed.) New Keynesian Economics/Post Keynesian Alternatives. London: Routledge.

Dow, S.C. (2004) "Uncertainty and monetary policy", Oxford Economic Papers, 56(3), 539-561.

European Commission (1990) "One market, one money. An evaluation of the potential benefits and costs of forming an economic and monetary union”, European Economy, 44, 347pp. Brussels: Directorate-General for economic and Financial Affairs of the Commission of the European Communities.

Fingleton, B. Garretsen, H. and Martin, R. (2015) "Shocking aspects of monetary union: the vulnerability of regions in Euroland", Journal of Economic Geography, 15: 907-934.

Friedman, M. and Meiselman, D. (1963) The relative stability of monetary velocity and the investment multiplier in the United States, in Commission of Money and Credit (ed.) Impacts of Monetary Policy, Englewood Cliffs: Prentice-Hall.

Holland, S. (1976), Capital Versus the Regions, London: Macmillan.

Mackay, R.R. and Molyneux, P. (1996) "Bank credit and the regions: a comparison within Europe", Regional Studies, 30(8): 757-763.

Martin, R. (2011) "The local geographies of the financial crisis: from the housing bubble to economic recession and beyond", Journal of Economic Geography, 11: 587-618.

Martin, R.L. (2001) "EMU versus the regions: regional convergence and divergence in Euroland", Journal of Economic Geography, 1: 51-80.

Miller, R J (1978) The Regional Impact of the Monetary Policy in the United States. Lexington, MA: Lexington Books.

Minsky, H.P. (1965) "Commercial banking and rapid economic growth in California”, in H.P. Minsky (ed.) California Banking in a Growing Economy. California: Institute of Business and Economic Research, 79-134.

Minsky, H.P. (1982) Inflation, Recession and Economic Policy. Brighton: Wheatsheaf.

O’Brien, R. (1992) Global Financial Integration: The End of Geography. New York: Council of Foreign Relations Press. 
Ohlin, B. (1933) Interregional and International Trade. Cambridge: Harvard University Press. Porteous, D.J. (1995) The Geography of Finance. Aldershot: Edward Elgar.

Rodriguez-Fuentes, C.J. (1998) "Credit availability and regional development", Papers in Regional Science, 77(1): 63-75.

Rodriguez-Fuentes, C.J. and Dow, S.C. (2003) "EMU and the regional impact of monetary policy", Regional Studies, 37(9): 973-984.

Rossi, S. (2013) "Financialisation and monetary union in Europe: the monetary-structural causes of the euro-area crisis", Cambridge Journal of Regions, Economy and Society, 6: 381-400.

Thornton, D L (2010) “The Downside of Quantitative Easing”, Federal Reserve Bank of St. Louis, Economic Synopsis, no. 34.

Turner, A. (2012) "Credit creation and social optimality", International Review of Financial Analysis, 25: $142-153$. 